\title{
What explains gender inequality in HIV infection among high-risk people? A Blinder-Oaxaca decomposition
}

\author{
Mansour Sajadipour', Satar Rezaei², Seyed Fahim Irandoost², Mohammadreza Ghaumzadeh', \\ Mohamadreza Salmani nadushan', Mohammad Gholami ${ }^{3}$, Yahya Salimi ${ }^{4^{*}}$ (D) and Zahra Jorjoran Shushtari ${ }^{5}$
}

\begin{abstract}
Background: Despite clear evidence on role of gender in vulnerability and exposure to HIV infection, information on gender-related inequalities in HIV and related factors are rarely documented. The aim of this study was to measure gender inequality in HIV infection and its determinates in Tehran city, the capital of Iran.

Methods: The study used the data of 20,156 medical records of high-risk people who were admitted to Imam Khomeini Voluntary Counseling and Testing site in Tehran from 2004 to 2018. The Blinder-Oaxaca decomposition was used to quantify the contribution of explanatory variables to the gap in the prevalence of HIV infection between female and male.

Results: The age-adjusted proportion of HIV infection was $9.45 \%$ (95\% Cl: $9.02,9.87)$. The absolute gap in the prevalence of HIV infection between male and female was 4.50\% (95\% Cl: $-5.33,-3.70 \%)$. The Blinder-Oaxaca decomposition indicated that most explanatory factors affecting the differences in HIV infection were job exposure, drug abuse, history of imprisonment, injection drug, heterosexual unsafe sex, and having an HIV-positive spouse.

Conclusion: The results can provide evidence for health policymakers to better planning and conducting genderbased preventive and screening programs. Policies aiming at promoting HIV preventive behaviors among male may reduce the gap in HIV infection between female and male in Iran.
\end{abstract}

Keywords: Gender inequality, HIV infection, High-risk people, Blinder-Oaxaca decomposition

\section{Background}

The human immunodeficiency virus (HIV) continues as one of the serious public health challenges in developing countries. According to the Global Burden of Disease Study, the annual incidence of HIV infection was about 2.6 million per year in 2015 [1]. About 37.7 million people living with HIV/AIDS in 2020 globally [2]. Of these, about 6.1 million infected people with HIV are not aware of their infection [3]. In 2020, 5.8 million

\footnotetext{
* Correspondence: salimiyahya@yahoo.com

${ }^{4}$ Social Development and Health Promotion Research Center, Health Institute, Kermanshah University of Medical Sciences, Kermanshah, Iran Full list of author information is available at the end of the article
}

people were living with HIV in Asia and the Pacific regional [3]. Estimation shows that the prevalence of HIV among the Iranian population age $\geq 18$ was 90 per 100,000 people (15,000 female and 39,000 male) in 2019 [4]. The incidence of HIV infected cases in all age groups in Iran was estimated 2.86 per 100,000 people [4]. Although HIV can affect people regardless of sexual orientation, race, ethnicity, gender, or age, some people are at higher risk for HIV than others and need special consideration because of their socio-demographic characteristics and risk factors.

Gender is one of the important social determinants of health which has an important role in health equity and

(c) The Author(s). 2021 Open Access This article is licensed under a Creative Commons Attribution 4.0 International License, which permits use, sharing, adaptation, distribution and reproduction in any medium or format, as long as you give appropriate credit to the original author(s) and the source, provide a link to the Creative Commons licence, and indicate if changes were made. The images or other third party material in this article are included in the article's Creative Commons licence, unless indicated otherwise in a credit line to the material. If material is not included in the article's Creative Commons licence and your intended use is not permitted by statutory regulation or exceeds the permitted use, you will need to obtain permission directly from the copyright holder. To view a copy of this licence, visit http://creativecommons.org/licenses/by/4.0/. The Creative Commons Public Domain Dedication waiver (http://creativecommons.org/publicdomain/zero/1.0/) applies to the data made available in this article, unless otherwise stated in a credit line to the data. 
well-being [5, 6]. "Gender is defined as a social concept that differentiates the power, roles, responsibilities, and obligations of women from that of men in society" [7]. Gender inequalities in health are manifested in a context in which access to, utilization of healthcare services, morbidity, and mortality differed preventable and unnecessarily between women and men in a society [8]. Gender inequalities affect health outcomes through various pathways. Some health outcomes are determined primarily by biological sex differences [9]. Other health outcomes are the results of socialization of the gender roles and gendered power relations supported by social norms about masculinity and femininity in societies. Gender usually is a stable social determinant of health during life-course, whereas some other social determinants such as education, income, and occupation could change during people's life. Female gender through economic dependency, intimate partner violence, and lack of power to negotiate safe sex can increase the risk of HIV infection [10-13]. Evidence shows that women are disproportionally affected by HIV around the world [7, 14]. This subpopulation may be more at risk, less detected, and less likely to receive timely and appropriate health care services and treatments. This situation makes reaching the 90-90-90 target, to control HIV infection hard. In addition, according to the literature, not only there is a gender inequality in health outcomes such as HIV, but also social consequences related to such health problems such as social stigma, coping, and social support differs among people based on their gender [14, 15]. As HIV related stigma has a strong negative effect on female, and men differently cope with stressful condition such as HIV status than female [16]. Despite the evidence highlighted on the role of gender in HIV infection, there is little empirical evidence about the role of gender difference as the main source of HIV infection inequality and its responsible factors among the developing countries $[7,10,14,17]$. It seems that HIV infection is disproportionally distributed by gender in Tehran, therefore we seek to examine this gender disparities and its determinants among people who refer to a behavioral consultation center in Tehran. Knowing about the magnitude of gender inequality and its determinants may provide an insight about gender distribution of the HIV infection that is necessary for effective HIV prevention programing and managing the limited resources for health planners.

\section{Methods}

The data used in this study come from 20,156 medical records of high-risk people who were admitted to Imam Khomeini Voluntary Counseling and Testing (VCT) site of Tehran University of Medical Sciences from 2004 to 2018. The Imam Khomeini VCT is among major site that provides free counseling, testing, and treatment services for people with high-risk behaviors, HIV-positive and patient with AIDS to cope with the test result and avoid high-risk behavior. The people who are identified as HIV positive will be given more information, posttesting counseling, and treatment. The routine data in the VCT were collected using a checklist that including some demographic data, behavioral information, and personal history.

HIV testing was performed at the VCT laboratory using a standard western blot test was performed to confirm HIV status. The outcome variable in this study was the HIV test result ( 0 , no; 1 , yes).

This study was approved by the Ethics Committee of Kermanshah University of Medical Sciences (IR.KUMS.REC.1398.364).

\section{Statistical analysis}

There were some missing data in the variables, therefore, we used Multiple Imputation (MI) to account for the missing values and assumed that the data were not missing completely at random.

The imputed data sets were analyzed using the MI suite of commands. The analyses were performed on 50 multiple imputed datasets. We used Blinder-Oaxaca (BO) decomposition with a logistic model $[18,19]$ to decompose the absolute difference in the HIV infection between female and male. In the BO model, the prevalence gap between female and male in HIV infection can be decomposed into two components: first, the percentage attributable to different levels of the explanatory variables between female and male (composition, endowment, or explained effect), and second the percentage attributable to explanatory variables having differential effects on HIV infection in female and male (response or coefficient effect). The following regression model linking the HIV infection, $Y$; to a set of predictors, $x$, eq. 1 and 2 are presented for female and male, respectively:

$$
Y F=\beta F x i+\varepsilon i F
$$

$$
Y M=\beta M x i+\varepsilon i M
$$

The difference between the mean values of HIV infection for the female, $y A$, and male, $y B$, can be calculated as:

$$
\begin{aligned}
Y M-Y F & =\Delta x B F+\Delta B x F+\Delta x \Delta \beta \\
& =E+C+C E
\end{aligned}
$$

where $x F$ and $x M$ are the average predictors for female and male, respectively; $\beta F$ and $\beta M$ denote the coefficients of predictors for female and male, respectively; and $\Delta x=x F-x M$ and $\Delta \beta=\beta F-\beta M$. Based on eq. 3 , the 
mean difference in the prevalence of HIV infection was divided into three components: first, the percentage attributable to different levels of predictors between female and male (explained components, E), second, the percentage attributable to predictors that have differential effects on HIV infection in female and male (the response or coefficient effect, $C$ ), and third, the percentage attributable to the interaction between the difference in the mean value of predictors and their coefficients $(C E)$. The nonlinear BO decomposition method with a logistic model to decompose the gap in HIV infection between female and male [20]. The level of significance (alpha level) in all analyses was set at 0.05. All statistical analysis procedures were done using STATA 11(version 11; StataCorp, TX, USA) [21].

\section{Results}

Table 1 present the descriptive characteristics of the study population included in the study. As indicated in Table 1 , nearly $70 \%$ of the study participants were men; most participants were $20-40$ years $(65.22 \%)$, and rarely used the condom (56.85\%). The majority of participants had academic education (54.35\%). Only $21.86 \%$ were drug abuse, and $19.99 \%$ had a history of prison. Ageadjusted proportion of HIV infection was $9.45 \%(95 \% \mathrm{Cl}$ : $9.02,9.87)$. There was a higher proportion of ageadjusted proportion of HIV infection among the male (10.50\%) compared to the female (7.15\%).

Table 2 shows the results from multiple logistic regression analysis for the association between HIV status and its determinants. There was a adjusted association between age and HIV infection $(\mathrm{OR}=1.03,95 \% \mathrm{CI}$ : 1.01 , 2.36). Male were more likely to get HIV infection than female (OR $=1.24,95 \% \mathrm{CI}: 1.05,1.47)$. History of imprisonment and drug abuse significantly increased the odds of being HIV positive by nearly $80 \%$. The unemployed people had a nearly four-fold increase in the odds of HIV infection compared to those who had a mobile job $(\mathrm{OR}=3.74,95 \% \mathrm{CI}: 1.86,7.50)$. People with an academic degree were less likely to have HIV infection compared to those who were illiterate $(\mathrm{OR}=0.48,95 \% \mathrm{CI}: 0.34$, 0.70).

\section{Blinder-Oaxaca decomposition analysis}

Tables 3 shows the results of the BO decomposition for determinants of HIV infection between female and male. The prevalence of HIV infection in female was $7.53 \%$ (95\% CI: $6.90,8.20 \%$ ), while the prevalence was $12.03 \%$ (95\% CI: 11.51,12.54\%) in male. The gap between female and male was $-4.50 \%$ (95\% CI: $-5.33,-3.70 \%)$. The results of the BO decomposition showed that $-136 \%$ of the gap between male and female could be explained by differences in the distribution of the variables included in the model. Differences in job exposure, drug abuse, history of imprisonment, injection drug, heterosexual unsafe sex, and having an HIV-positive spouse were the main determinants that affected the difference in the prevalence of HIV infection between the female and male. Figure 1 presents the contribution of determinants in the total gap of differences in HIV infection among high-risk people, Tehran, 2004 to 2018.

The unexplained part of the difference between the female and male was $302.65 \%$ that may be attributed to differences in the coefficients of included determinants or other determinants that we were not included in the model. The share of the interaction component in the total gap between female and male was $68.86 \%$ (Table 3).

\section{Discussion}

To develop effective HIV prevention and therapeutic interventions, it is important to identify the demographic characteristics of infected people. This study provides evidence about gender inequality in HIV infection and its responsible factors among high-risk people in Tehran. Our finding showed that there is a difference in the HIV infection between female and male. Male were more likely to get HIV infection than female. The difference in the manifestations of HIV infection among the female and male may have several individual and social reasons. This could be due to combined influences of inherent physiological factors (sex) and gendered social bias or through gendered social bias alone [22]. Where physiological sex differences interact with social factors, it defines different needs and influences exposure and vulnerability to health risks [22]. Specifically, in context of our study, this specific gender difference not only influence the acquisition of the virus but also the progression of the disease that policy efforts must address them to prevent risk outcome among at high-risk population. Also, some social factors such as social stigma and social network characteristics can increase likelihood of HIV risk behaviors [23-25] among male which can contribute to the observed gap between male and female. Living with HIV is along with social stigma in Iran, and based on the evidence this social stigma is higher among women than men $[26,27]$, because the community may think that those infected women especially those who are single may have premarital sex, deviant sexual behavior, and were infected via sexual relationships. Therefore, female are less likely to seek HIV testing services than men due to the profound social stigma associated with HIV, however, they usually more disclose their HIV status to their private network [28]. Another possible explanation is that Iranian male has a larger network size than female which can result in having more frequency of contact with people having HIV risk behaviors, receiving negative social support enhancing HIV risk behaviors 
Table 1 Characteristics of study participants who admitted to Imam Khomeini Voluntary Counseling and Testing by HIV infection, Tehran, Iran (2004-2018)

\begin{tabular}{|c|c|c|c|c|c|}
\hline & $\begin{array}{l}\mathrm{HIV}^{+} \\
N(\%)\end{array}$ & $\begin{array}{l}\mathrm{HIV}^{-} \\
N(\%)\end{array}$ & $\begin{array}{l}\text { All participants } \\
N(\%)\end{array}$ & Pvalue & $\begin{array}{l}\text { Missing } \\
N(\%)\end{array}$ \\
\hline Age groups & & & & $<0.001$ & $99(0.49)$ \\
\hline$<20 y$ & $62(7.21)$ & $798(92.79)$ & $860(4.29)$ & & \\
\hline $20-40$ y & $818(6.26)$ & $12,245(93.74)$ & $13,063(65.22)$ & & \\
\hline $40-60$ y & $1130(20.91)$ & $4274(79.09)$ & $5404(26.98)$ & & \\
\hline$>60$ & $129(18.38)$ & $573(81.62)$ & $702(3.50)$ & & \\
\hline Gender & & & & $<0.001$ & $72(0.36)$ \\
\hline Male & $1685(12.01)$ & $12,345(87.99)$ & $14,030(69.95)$ & & \\
\hline Female & $455(7.55)$ & $5571(92.45)$ & $6026(30.05)$ & & \\
\hline Marital status & & & & $<0.001$ & $17,509(86.99)$ \\
\hline Single & $250(30.05)$ & $582(69.95)$ & $1073(40.97)$ & & \\
\hline Married & $240(22.37)$ & $833(77.63)$ & $832(31.77)$ & & \\
\hline Divorced & $72(15.96)$ & $379(84.04)$ & $451(17.22)$ & & \\
\hline Widowed & $26(55.32)$ & $21(44.68)$ & $47(1.79)$ & & \\
\hline Other & $4(1.85)$ & $212(98.15)$ & $216(8.25)$ & & \\
\hline History of imprisonment & & & & $<0.001$ & $8262(41.05)$ \\
\hline No & $507(5.34)$ & $8987(94.66)$ & $9494(80.01)$ & & \\
\hline Yes & $1154(48.65)$ & $1218(51.35)$ & $2372(19.99)$ & & \\
\hline Drug abuse & & & & $<0.001$ & $8411(41.79)$ \\
\hline No & $427(4.66)$ & $8729(95.34)$ & $9156(78.14)$ & & \\
\hline Yes & $1208(47.17)$ & $1353(52.83)$ & $2561(21.86)$ & & \\
\hline Condom use & & & & $<0.001$ & $12,174(60.48)$ \\
\hline Never & $298(13.48)$ & $1913(86.52)$ & $2211(27.80)$ & & \\
\hline Rarely & $386(8.54)$ & $4136(91.46)$ & $4.522(56.85)$ & & \\
\hline Ever & $79(6.47)$ & $1142(93.53)$ & $1221(15.35)$ & & \\
\hline Job title & & & & $<0.001$ & $281(1.40)$ \\
\hline Far from home & $10(8.47)$ & $108(91.53)$ & $118(0.59)$ & & \\
\hline Risky environment & $20(1.00)$ & $1990(99.00)$ & $2010(10.13)$ & & \\
\hline Official & $967(9.51)$ & 9199 (90.49) & $10,166(51.22)$ & & \\
\hline Unemployed & $1098(18.15)$ & $4953(81.85)$ & $6051(30.49)$ & & \\
\hline Student & $34(2.26)$ & $1468(97.74)$ & $1502(7.57)$ & & \\
\hline Educational level & & & & $<0.001$ & $11,250(55.89)$ \\
\hline Illiterate & $68(40.72)$ & $99(59.28)$ & $167(1.88)$ & & \\
\hline Elementary & $297(45.00)$ & $363(55.00)$ & $660(7.43)$ & & \\
\hline Junior & $450(37.82)$ & $740(62.18)$ & $1190(13.40)$ & & \\
\hline High school & $303(14.88)$ & $1733(85.12)$ & $2036(22.93)$ & & \\
\hline Academic & 154 (3.19) & $4671(96.81)$ & $4825(54.35)$ & & \\
\hline Root of transmission & & & & $<0.001$ & $72(0.36)$ \\
\hline Injection drug & $1166(35.18)$ & $2148(64.82)$ & 3314 (16.52) & & \\
\hline Unsafe sex (heterosexual) & $322(3.36)$ & $9272(96.64)$ & $9594(47.84)$ & & \\
\hline Unsafe sex (homosexual) & $37(8.04)$ & $423(91.96)$ & $460(2.29)$ & & \\
\hline Blood and blood products & $23(37.70)$ & $38(62.30)$ & $61(0.30)$ & & \\
\hline Vertical transfer & $50(10.46)$ & $428(89.54)$ & $478(2.38)$ & & \\
\hline
\end{tabular}


Table 1 Characteristics of study participants who admitted to Imam Khomeini Voluntary Counseling and Testing by HIV infection, Tehran, Iran (2004-2018) (Continued)

\begin{tabular}{|c|c|c|c|c|c|}
\hline & $\begin{array}{l}\mathrm{HIV}^{+} \\
N(\%)\end{array}$ & $\begin{array}{l}\text { HIV }^{-} \\
N(\%)\end{array}$ & $\begin{array}{l}\text { All participants } \\
N(\%)\end{array}$ & Pvalue & $\begin{array}{l}\text { Missing } \\
N(\%)\end{array}$ \\
\hline High risk spouse & $77(12.44)$ & $542(87.56)$ & 619 (3.09) & & \\
\hline $\mathrm{HIV}^{+}$Spouse & $205(27.55)$ & $539(72.45)$ & 744 (3.71) & & \\
\hline Job Exposure & $5(0.24)$ & $2111(99.76)$ & $2116(10.55)$ & & \\
\hline Unknown & $255(9.55)$ & $2415(90.45)$ & $2670(13.31)$ & & \\
\hline
\end{tabular}

and experiencing more risky behaviors which can make male more vulnerable to HIV infection than female [23$25,29,30]$. Moreover, social norms related to male role in sexual relationships, such as being powerful, and determinator about condoms use behavior can led to unsafe sex and consequently HIV infection. Some qualitative studies among at risk female in Iran found that male have more control over condom use decisions than female as many of female participants believed that male have greater authority and domination in decisionmaking control over condom use and female are expected to yield to male desires for sex and condom use $[11,31]$. This finding suggests that a gender-based HIV prevention intervention is necessary. Also, HIV-related interventions must consider gender stereotypes in Iranian society to reduce the social stigma and HIV prevalence gap between men and women. Our finding regarding the gender inequality in HIV infection is not consistent with previous studies [32-35]. A systematic review conducted in 2012, reported a significantly higher HIV prevalence among female compared to male who injects drugs [33]. One study was conducted in the USA, which enrolled 769 intravenous drug users, found that the gender of the participants was unrelated to their HIV status [32]. This controversy may be due to differences in methodological aspects, and social and cultural aspects among the studies.

We also found the main determinants of the observed difference in HIV infection between female and male. Our finding showed that job exposure, drug abuse, history of imprisonment, injecting drugs, heterosexual unsafe sex, and having an HIV-positive spouse were the main contributors to the difference in the prevalence of HIV infection between the female and male. Consistent with previous studies, our finding showed that male tended to have riskier sexual behavior, more use or injecting drugs, and history of imprisonment than female $[7,10,14,36]$. These determinants may contribute to gender inequalities in HIV infection by providing a highrisk environment which increases the probability of HIV infection. One study showed that the majority of female involved in lower levels of jobs in health care, which increase risks of infection [37]. However, male generally works in environments with greater risk for job exposure
[38]. In our study only $2.3 \%$ of people reported homosexual unsafe sex and nearly all (99.99\%) of them were male. One explanation for the opposite effect of hetero and homo sexual unsafe sex on the gender difference in prevalence of HIV infection is that in a Muslim country, such as Iran, homosexuality is forbidden and banned by the religion and government, therefore this type of sexual behavior is very restricted and underreported. Therefore, any intervention in this term may result in identifying more HIV infected cases. As expected, the gap in HIV infection is reduced substantially when drug abuse, history of imprisonment, injecting drugs, heterosexual unsafe sex is taken into account. Our finding highlights that for HIV/AIDS prevention programs to be effective it is critical to be targeted and consider job characteristics, the history of drug abuse, history of imprisonment, and HIV risk behaviors of at-risk people especially men.

Our study had four limitations that should be considered when interpreting the study findings. First, we used the data that come from medical records of high-risk people that are volunteer to receive free counseling, testing, and treatment services; therefore, our results could be biased due to self-volunteer bias. Second, because our study design was cross-sectional, we are not able to establish any causal relationship between HIV infection and its main determinants included in the analysis. Third, the root of transmission was self-reported and may be reported with some degree of measurements error. Fourth, a proportion of people had missing data, we assume that the missing data are at random. However, to account for missing data, we used multiple imputations using chained equations.

\section{Conclusion}

The findings can provide evidence for health policymakers and decision-makers to better planning and conducting gender-based preventive and screening programs to reduce the gender gap in HIV infection. Taking into consideration these gender differences is very important for effective HIV prevention and treatment interventions in a resource-limited setting, such as Iran. The results of the present study point to the importance of looking at multiple determinants when 
Table 2 Multiple logistic regression results of determinants of HIV infection who admitted to Imam Khomeini Voluntary Counseling and Testing $(n=20,128)$, Tehran, Iran (2004-2018)

\begin{tabular}{|c|c|c|c|c|}
\hline Variables & Crude OR & $95 \% \mathrm{Cl}$ & Adjusted OR & $95 \% \mathrm{Cl}$ \\
\hline Age & $1.05^{* * *}$ & $1.05,1.06$ & $1.03^{* * *}$ & $1.01,1.05$ \\
\hline \multicolumn{5}{|l|}{ Gender } \\
\hline Female & ref & ref & ref & ref \\
\hline Male & $1.67^{* * *}$ & $1.50,1.86$ & $1.24^{* *}$ & $1.05,1.47$ \\
\hline \multicolumn{5}{|l|}{ Marital status } \\
\hline Married & ref & ref & ref & ref \\
\hline Single & 1.00 & $0.84,1.20$ & 0.89 & $0.75,1.05$ \\
\hline Widowed & 1.53 & $0.96,2.43$ & 1.33 & $0.86,2.05$ \\
\hline Divorced & $0.83^{* * *}$ & $0.68,1.01$ & $0.80^{* *}$ & $0.65,0.98$ \\
\hline Other & $0.62^{* * *}$ & $0.45,0.87$ & $0.59^{* * *}$ & $0.44,0.79$ \\
\hline \multicolumn{5}{|l|}{ History of imprisonment } \\
\hline No & ref & ref & ref & ref \\
\hline Yes & $8.24^{* * *}$ & $7.41,9.17$ & $1.83^{* * *}$ & $1.47,2.28$ \\
\hline \multicolumn{5}{|l|}{ Drug abuse } \\
\hline No & ref & ref & ref & ref \\
\hline Yes & $8.00^{* * *}$ & $7.19,8.91$ & $1.80^{* * *}$ & $1.43,2.26$ \\
\hline \multicolumn{5}{|l|}{ Condom use } \\
\hline Never & ref & ref & ref & ref \\
\hline Rarely & $0.72^{* * *}$ & $0.63,0.82$ & 0.94 & $0.81,1.09$ \\
\hline Ever & $0.58^{* * *}$ & $0.47,0.70$ & 0.92 & $0.74,1.14$ \\
\hline \multicolumn{5}{|l|}{ Job title } \\
\hline Far from home & ref & ref & ref & ref \\
\hline Risky environment & $0.11^{* * *}$ & $0.05,0.24$ & 1.20 & $0.51,2.81$ \\
\hline Official & $1.14^{* *}$ & $0.60,2.18$ & $2.57^{* *}$ & $1.28,5.15$ \\
\hline Unemployed & $2.39^{* * *}$ & $1.25,4.59$ & $3.74^{* *}$ & $1.86,7.50$ \\
\hline Student & $0.25^{* * *}$ & $0.12,0.52$ & 1.47 & $0.67,3.22$ \\
\hline \multicolumn{5}{|l|}{ Educational level } \\
\hline Illiterate & ref & ref & ref & ref \\
\hline Elementary & $1.13^{* * *}$ & $0.83,1.53$ & 1.07 & $0.75,1.52$ \\
\hline Junior & $0.96^{*}$ & $0.71,1.30$ & 1.04 & $0.73,1.47$ \\
\hline High school & $0.40^{* * *}$ & $0.29,0.53$ & 0.85 & $0.59,1.21$ \\
\hline Academic & $0.12^{* * *}$ & $0.09,0.16$ & 0.48 & $0.34,0.70$ \\
\hline \multicolumn{5}{|l|}{ Root of transmission } \\
\hline Injection drug & ref & ref & ref & ref \\
\hline Unsafe sex (heterosexual) & $0.06^{* * *}$ & $0.05,0.07$ & $0.21^{* * *}$ & $0.18,0.25$ \\
\hline Unsafe sex (homosexual) & $0.16^{* * *}$ & $0.11,0.23$ & $0.64^{*}$ & $0.44,0.93$ \\
\hline Blood and blood products & 1.11 & $0.66,1.88$ & $2.84^{* *}$ & $1.57,5.13$ \\
\hline Vertical transfer & $0.22^{* * *}$ & $0.16,0.29$ & 1.04 & $0.68,1.58$ \\
\hline High risk spouse & $0.26^{* * *}$ & $0.20,0.34$ & 0.75 & $0.55,1.02$ \\
\hline $\mathrm{HIV}^{+}$Spouse & $0.70^{* * *}$ & $0.59,0.84$ & $1.66^{* *}$ & $1.29,2.13$ \\
\hline Job Exposure & $0.004^{* * *}$ & $0.002,0.01$ & $0.023^{* * *}$ & $0.009,0.06$ \\
\hline Unknown & $0.19^{* * *}$ & $0.17,0.23$ & $0.45^{* * *}$ & $0.38,0.54$ \\
\hline
\end{tabular}

${ }^{*} p<0.05,{ }^{* *} p<0.01,{ }^{* * *} p<0.001$ 
Table 3 Blinder-Oaxaca decomposition of the prevalence of HIV infection among high-risk people, Tehran, Iran (2004-2018)

\begin{tabular}{|c|c|c|c|}
\hline & Prediction (\%) & $95 \% \mathrm{Cl}$ & Total gap (percent) $^{\mathrm{a}}$ \\
\hline Female & $7.53^{* * *}$ & $6.90,8.20$ & \\
\hline Male & $12.03^{* * *}$ & $11.51,12.54$ & \\
\hline Total gap & $-4.50^{* * *}$ & $-5.33,-3.70$ & \\
\hline \multicolumn{4}{|l|}{ Due to endowment (explained) } \\
\hline Age (year) & $-0.36^{* * *}$ & $-0.49,-0.22$ & 7.89 \\
\hline \multicolumn{4}{|l|}{ Educational level } \\
\hline Illiterate & 0.001 & $-0.008,0.01$ & -0.03 \\
\hline Elementary & $-0.05^{*}$ & $-0.09,-0.003$ & 1.00 \\
\hline Junior & $-0.09^{*}$ & $-0.16,-0.02$ & 2.03 \\
\hline High school & -0.001 & $-0.01,0.01$ & 0.02 \\
\hline Academic & $-0.36^{* * *}$ & $-0.53,-0.20$ & 8.09 \\
\hline \multicolumn{4}{|l|}{ Condom use } \\
\hline Never & 0.03 & $-0.01,0.07$ & -0.58 \\
\hline Rarely & 0.001 & $-0.02,0.02$ & -0.02 \\
\hline Ever & 0.014 & $-0.02,0.05$ & -0.31 \\
\hline Drug abuse (yes) & $-0.86^{* * *}$ & $-1.25,-0.46$ & 19.07 \\
\hline History of imprisonment (yes) & $-1.07^{* * *}$ & $-1.50,-0.70$ & 23.88 \\
\hline Injection drug (yes) & $-2.22^{* * *}$ & $-2.70,-1.74$ & 49.33 \\
\hline Heterosexual unsafe sex (yes) & $1.34^{* * *}$ & $0.99,1.68$ & -29.69 \\
\hline Homosexual unsafe sex (yes) & $-0.23^{* *}$ & $-0.38,-0.09$ & 5.15 \\
\hline Job Exposure (yes) & $-2.77^{* * *}$ & $-3.35,-2.19$ & 61.54 \\
\hline HIV + Spouse (yes) & 0.51 & $-0.03,1.05$ & -11.38 \\
\hline Sub-total of gap (explained part) & $-6.12^{* * *}$ & $-9.50,-2.73$ & 136.00 \\
\hline \multicolumn{4}{|l|}{ Due to response (unexplained) } \\
\hline Age (year) & -4.91 & $-14.82,4.99$ & 109.12 \\
\hline \multicolumn{4}{|l|}{ Educational level } \\
\hline Illiterate & 0.12 & $-0.14,0.38$ & -2.66 \\
\hline Elementary & 0.063 & $-0.35,0.47$ & -1.40 \\
\hline Junior & -0.05 & $-0.75,0.65$ & 1.07 \\
\hline High school & -0.41 & $-1.56,0.74$ & 9.11 \\
\hline Academic & -1.91 & $-5.32,1.49$ & 42.44 \\
\hline \multicolumn{4}{|l|}{ Condom use } \\
\hline Never & -0.31 & $-1.33,0.72$ & 6.78 \\
\hline Rarely & -0.12 & $-1.79,1.54$ & 2.74 \\
\hline Ever & 0.23 & $-0.55,1.00$ & -5.05 \\
\hline Drug abuse (yes) & -0.32 & $-2.54,1.91$ & 7.06 \\
\hline History of imprisonment (yes) & -4.06 & $-11.29,3.17$ & 90.22 \\
\hline Injection drug (yes) & 1.72 & $-1.20,4.63$ & -38.20 \\
\hline Heterosexual unsafe sex (yes) & -2.90 & $-7.63,1.82$ & 64.54 \\
\hline Homosexual unsafe sex (yes) & -0.28 & $-0.80,0.25$ & 6.15 \\
\hline Job Exposure (yes) & -0.56 & $-1.86,0.73$ & 12.54 \\
\hline HIV + Spouse (yes) & 0.08 & $-0.07,0.24$ & -1.82 \\
\hline Sub-total of gap (Unexplained part) & -13.62 & $-51.98,24.75$ & 302.65 \\
\hline Interaction & $3.10^{* *}$ & $0.94,5.25$ & -68.86 \\
\hline
\end{tabular}

${ }^{a}$ Calculated by dividing the determinant's prediction value by the total gap $(-4.5),{ }^{*} p<0.05,{ }^{* *} p<0.01,{ }^{* * *} p<0.001$ 


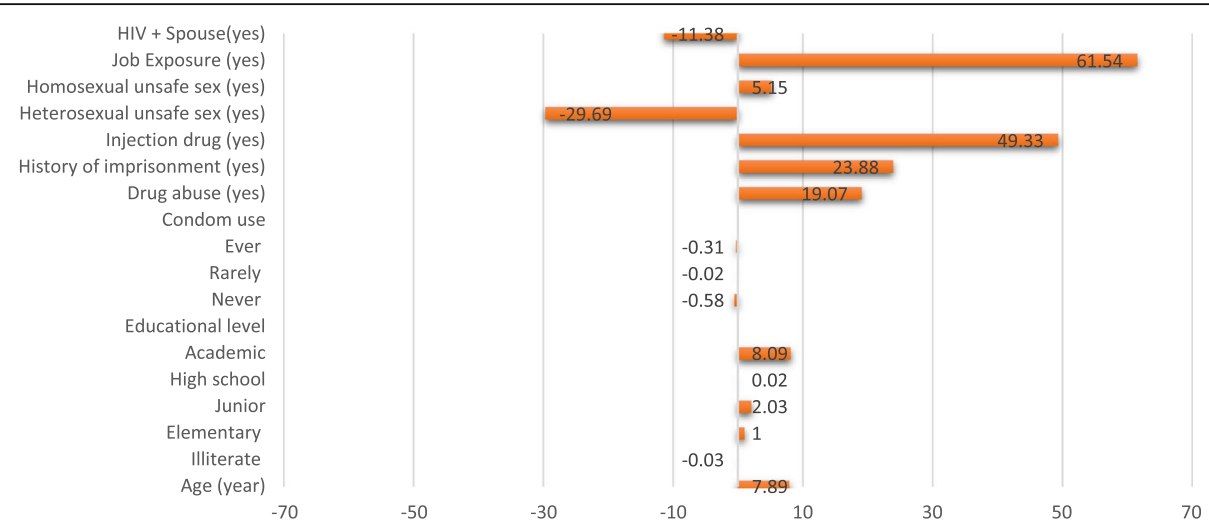

Fig. 1 Contribution of determinants in total gap of differences in HIV infection among high-risk people, Tehran, Iran (2004-2018)

assessing gender inequality. Also, our finding highlights that policies and programs aimed at change the job exposure, drug abuse, history of imprisonment, injection drug, and heterosexual unsafe sex among the male may reduce the gap in HIV infection between female and male in Iran.

\section{Abbreviations}

HIV: Human immunodeficiency virus; VCT: Voluntary Counseling and Testing; MI: Multiple Imputation; BO: Blinder-Oaxaca; CE: Coefficients

\section{Acknowledgments}

We gratefully thank all staff in the Imam Khomeini Voluntary Counseling and Testing.

\section{Authors' contributions}

MS, SR, SFI, MGH,MSN and ZJSH design and conducted the search. YS, MGH, $M S$, and SR contributed to the data analysis and drafting the manuscript, and SFI, MGH, and ZJSH revised the manuscript. All authors read and approved the final manuscript.

\section{Availability of data and materials}

The datasets used and/or analyzed during the current study are available from the corresponding author on reasonable request.

\section{Declarations}

\section{Ethics approval and consent to participate}

The study was approved by the Ethics Review Committee of the Deputy of Research at Kermanshah University of Medical Sciences (IR.KUMS.REC.1398.364).

\section{Consent for publication}

Not applicable.

\section{Competing interests}

There is no conflict of interest to be declared.

\section{Author details}

${ }^{1}$ Department of Health, South Tehran health center, Tehran University of Medical Sciences, Tehran, Iran. ${ }^{2}$ Social Determinants of Health Research Center, Clinical Research Institute, Urmia University of Medical Sciences, Urmia, Iran. ${ }^{3}$ Department of Medical Microbiology, Aja University of Medical Sciences, Tehran, Iran. ${ }^{4}$ Social Development and Health Promotion Research Center, Health Institute, Kermanshah University of Medical Sciences, Kermanshah, Iran. ${ }^{5}$ Social Determinants of Health Research Center, University of Social Welfare and Rehabilitation Sciences, Tehran, Iran.
Received: 18 December 2020 Accepted: 11 December 2021

Published online: 04 January 2022

\section{References}

1. Wang H, Wolock TM, Carter A, Nguyen G, Kyu HH, Gakidou E, et al. Estimates of global, regional, and national incidence, prevalence, and mortality of HIV, 1980-2015: the global burden of disease study 2015. Lancet HIV. 2016;3(8):e361-87. https://doi.org/10.1016/S2352-3018(16)30087$X$.

2. Global Health Observatory $(\mathrm{GHO})$ data.

3. HIV/AIDS JUNPo: UNAIDS data. UNAIDS: Geneva. Switzerland Retrieved Oct. 2020;15(2021):2021.

4. Country factsheets, Islamic Republic of Iran. available at: https://www. unaids.org/en/regionscountries/countries/islamicrepublicofiran.

5. Phillips SP. Defining and measuring gender: a social determinant of health whose time has come. Int J Equity Health. 2005;4(1):11. https://doi.org/10.11 86/1475-9276-4-11.

6. Organization $\mathrm{WH}$ : A conceptual framework for action on the social determinants of health. 2010.

7. Rao Gupta G, Whelan D, Allendorf K. Integrating gender into HIV; 2003.

8. Kawachi I, Subramanian S, Almeida-Filho N. A glossary for health inequalities. J Epidemiol Community Health. 2002;56(9):647-52. https://doi. org/10.1136/jech.56.9.647.

9. Regitz-Zagrosek V. Sex and gender differences in health. EMBO Rep. 2012; 13(7):596-603. https://doi.org/10.1038/embor.2012.87.

10. Tallis V. Gender and HIV/AIDS. Overview Rep. 2002

11. Lotfi R, Ramezani Tehrani F, Merghati Khoei E, Yaghmaei F, Dworkin SL. How do women at risk of HIV/AIDS in Iran perceive gender norms and gendered power relations in the context of safe sex negotiations. Arch Sex Behav. 2013;42(5):873-81. https://doi.org/10.1007/s10508-012-0040-6.

12. Jorjoran Shushtari Z, Hosseini SA, Sajjadi H, Salimi Y, Shahesmaeili A, Snijders TAB. Safe sex norm questionnaire for female sex workers: development and validation study in Iran. Public Health. 2018;164:82-90. https://doi.org/10.101 6/j.puhe.2018.07.023.

13. Jorjoran Shushtari Z, Salimi Y, Hosseini S, Sajjadi H, Snijders TAB. Determinants of safe sexual behavior of female sex workers in Tehran: the woman, her network, and the sexual partner. BMC public health. 2021; Accepted.

14. Türmen T. Gender and HIV/aids. Int J Gynecol Obstet. 2003;82(3):411-8. https://doi.org/10.1016/S0020-7292(03)00202-9.

15. Colbert AM, Kim KH, Sereika SM, Erlen JA. An examination of the relationships among gender, health status, social support, and HIV-related stigma. J Assoc Nurses AIDS Care. 2010;21(4):302-13. https://doi.org/10.101 6/j.jana.2009.11.004.

16. Gonzalez A, Miller CT, Solomon SE, Bunn JY, Cassidy DG. Size Matters: Community Size, HIV Stigma, \& Gender Differences. AIDS Behav. 2009;13(6): 1205-12. https://doi.org/10.1007/s10461-008-9465-2.

17. Richardson ET, Collins SE, Kung T, Jones JH, Tram KH, Boggiano VL, et al. Gender inequality and HIV transmission: a global analysis. J Int AIDS Soc 2014;17(1):19035. https://doi.org/10.7448/IAS.17.1.19035. 
18. Oaxaca R. Male-female wage differentials in urban labor markets. Int Econ Rev. 1973;14(3):693-709. https://doi.org/10.2307/2525981.

19. Jann B. The blinder-Oaxaca decomposition for linear regression models. Stata J. 2008;8(4):453-79. https://doi.org/10.1177/1536867X0800800401.

20. Sinning M, Hahn M, Bauer TK. The blinder-Oaxaca decomposition for nonlinear regression models. Stata J. 2008;8(4):480-92. https://doi.org/10.11 77/1536867X0800800402.

21. StataCorp L. Stata statistical software, version 11. StataCorp LP: StataCorp College Station (TX); 2009.

22. Sen G, Östlin P, George A. Unequal, unfair, ineffective and inefficient: gender inequity in health: why it exists and how we can change it: final report to the WHO Commission on social determinants of health: World Health Organization; 2007.

23. Brooks A, Meade CS, Potter JS, Lokhnygina Y, Calsyn DA, Greenfield SF. Gender differences in the rates and correlates of HIV risk behaviors among drug abusers. Subst Use Misuse. 2010;45(14):2444-69. https://doi.org/10.31 09/10826084.2010.490928.

24. Kang S-Y, Deren S, Andia J, Colón HM, Robles R. Gender differences in HIV risk behaviors among Puerto Rican drug injectors by awareness of HIV seropositive status. AIDS Behav. 2001;5(3):241-9. https:/doi.org/10.1023/A:1011340626507.

25. Shuter J, Alpert PL, DeShaw MG, Greenberg B, Chang CI, Klein RS. Gender differences in HIV risk behaviors in an adult emergency department in new York City. J Urban Health. 1999;76(2):237-46. https://doi.org/10.1007/BF02344679.

26. Karamouzian M, Akbari M, Haghdoost A-A, Setayesh H, Zolala F. "I am dead to them": HIV-related stigma experienced by people living with HIV in Kerman, Iran. J Assoc Nurses AIDS Care. 2015;26(1):46-56. https://doi.org/1 0.1016/j.jana.2014.04.005

27. Dejman M, Ardakani HM, Malekafzali B, Moradi G, Gouya MM, Shushtari Z et al. Psychological, social, and familial problems of people living with HIV/ AIDS in Iran: a qualitative study. Int J Prev Med. 2015;6(1):126. https://doi. org/10.4103/2008-7802.172540.

28. Shushtari ZJ, Sajjadi H, Forouzan AS, Salimi Y, Dejman M. Disclosure of HIV status and social support among people living with HIV. Iran Red Crescent Med J. 2014;16(8). https://doi.org/10.5812/ircmj.11856.

29. Shushtari ZJ, Hosseini SA, Sajiadi H, Salimi Y, Latkin C, Snijders TAB. Social network and HIV risk behaviors in female sex workers: a systematic review. BMC Public Health. 2018:18(1):1020. https:/doi.org/10.1186/s12889-018-5944-1.

30. Forouzan AS, Jorjoran Shushtari Z, Sajjadi H, Salimi Y, Dejman M. Social support network among people living with HIV/AIDS in Iran. AIDS Res Treat. 2013;2013:715381.

31. Lotfi R, Tehrani FR, Yaghmaei F, Hajizadeh E. Barriers to condom use among women at risk of HIV/AIDS: a qualitative study from Iran. BMC Womens Health. 2012;12(1):1-10. https://doi.org/10.1186/1472-6874-12-13.

32. Freeman RC, Rodriguez GM, French JF. A comparison of male and female intravenous drug Users' risk behaviors for HIV infection. Am J Drug Alcohol Abuse. 1994:20(2):129-57. https://doi.org/10.3109/00952999409106779.

33. Des Jarlais DC, Feelemyer JP, Modi SN, Arasteh K, Hagan H. Are females who inject drugs at higher risk for HIV infection than males who inject drugs: an international systematic review of high seroprevalence areas. Drug Alcohol Depend. 2012:124(1):95-107. https://doi.org/10.1016/j.drugalcdep.2011.12.020.

34. Magadi MA. Understanding the gender disparity in HIV infection across countries in sub-Saharan Africa: evidence from the demographic and health surveys. Soc Health IIness. 2011;33(4):522-39. https://doi.org/10.1111/j.1467-9566.2010.01304x.

35. Sia D, Onadja Y, Hajizadeh M, Heymann SJ, Brewer TF, Nandi A. What explains gender inequalities in HIV/AIDS prevalence in sub-Saharan Africa? Evidence from the demographic and health surveys. BMC Public Health. 2016;16(1):1136. https://doi.org/10.1186/s1 2889-016-3783-5.

36. Boileau C, Zunzunegui MV, Rashed S. Gender differences in unsafe sexual behavior among young people in urban Mali. AIDS Care. 2009;21(8):101424. https://doi.org/10.1080/09540120802626162.

37. Aiken LH, Clarke SP, Sloane DM, Sochalski J, Silber JH. Hospital nurse staffing and patient mortality, nurse burnout, and job dissatisfaction. Jama. 2002 288(16):1987-93. https://doi.org/10.1001/jama.288.16.1987.

38. Laflamme L, EILERT-PETERSSON E. Injury risks and socioeconomic groups in different settings: differences in morbidity between men and between women at working ages. Eur J Public Health. 2001;11(3):309-13. https://doi. org/10.1093/eurpub/11.3.309.

\section{Publisher's Note}

Springer Nature remains neutral with regard to jurisdictional claims in published maps and institutional affiliations.

\section{Ready to submit your research? Choose BMC and benefit from:}

- fast, convenient online submission

- thorough peer review by experienced researchers in your field

- rapid publication on acceptance

- support for research data, including large and complex data types

- gold Open Access which fosters wider collaboration and increased citations

- maximum visibility for your research: over $100 \mathrm{M}$ website views per year

At BMC, research is always in progress.

Learn more biomedcentral.com/submissions 